\title{
Premeal Consumption of a Protein-Enriched, Dietary Fiber-Fortified Bar Decreases Total Energy Intake in Healthy Individuals (Diabetes Metab J 2019;43:879-92)
}

\author{
Mi-kyung Kim \\ Department of Internal Medicine, Inje University College of Medicine, Busan, Korea
}

World Health Organization reported that obesity has nearly tripled worldwide since 1975 [1]. The solution for obesity is simply reducing energy intake below energy expenditure, but we cannot easily control eating. That is why various dietary strategies are being studied and debated. Revised 2020 American Diabetes Association nutritional guideline recommends that there is not an ideal percentage of calories from carbohydrate, protein, and fat for weight reduction [2]. Therefore, the best eating pattern should be individualized based on current eating patterns, preferences, and metabolic goals.

I enjoyed reading the interesting paper entitled "Premeal consumption of a protein-enriched, dietary fiber-fortified bar decreases total energy intake in healthy individuals" [3]. This study shows us that premeal supplement combined with a modest amount of protein and dietary fiber decreased total food intake compared to water control. Protein-enriched, dietary fiber-fortified bar (PFB) also decreased postprandial glucose levels. Glucagon-like peptide-1 (GLP-1) was prominently increased after PFB preload compared to both the usual bar and water control, but they discussed the difference of test meal intake was related to peptide YY (PYY) level, not GLP-1 level.

Satiety is a major factor for food intake control but is composed of a very complex mechanism. Satiety is first elicited by the gut distension response to portion size, volume and weight rather than to caloric and energy intake [4]. Among macronu- trients, previous studies reported that protein induced much stronger satiety than fat and carbohydrate in same calorie $[5,6]$. High-protein diets demonstrated a long-term impact on weight loss than iso-calorically dense high-carbohydrate or high-fat diets in clinical trials $[7,8]$. Amino acids in the gastrointestinal (GI) tract induce the release of cholecystokinin (CCK) and anorexigenic substances such as GLP-1 and PYY [9-12]. Thus, prioritizing protein early in the meal before carbohydrate and fat could decrease total food consumption due to better satiating effect.

This study reviewed previous studies about preload protein supplementation and suggested that they did not reduced total energy intake because of dose-dependent effect of premeal soy protein. To solve the problem, they used a smart combination which is composed of reduced amount of protein and fortified fiber for their premeal supplement.

Fiber is also a satiating component with very low calorie. This study reviewed the effect of fiber on bulk formation, gastric emptying, various hormones like GLP-1 and PYY, and microbiome through fermentation to small-chain fatty acids [3]. This study used dietary fiber. Some studies reported that soluble fibers with high viscosity slow digestion, increase absorption of macronutrients and extend the release of appetite-regulating hormones $[13,14]$. However, insoluble fibers, which provide bulk to the diet and increase the rate of transit, are less satiating and hunger-suppressing [15]. The character of fiber
Corresponding author: Mi-kyung Kim (D) https://orcid.org/0000-0003-1111-9122 Department of Internal Medicine, Inje University Haeundae Paik Hospital, Inje University College of Medicine, 875 Haeun-daero, Haeundae-gu, Busan 48108, Korea

E-mail:kmkdoc@paik.ac.kr
This is an Open Access article distributed under the terms of the Creative Commons Attribution Non-Commercial License (https://creativecommons.org/licenses/by-nc/4.0/) which permits unrestricted non-commercial use, distribution, and reproduction in any medium, provided the original work is properly cited. 
may be another factor that influenced the results.

One study demonstrated sex-specific central processing of hunger and satiety cues [16]. These investigators reported differences in neuronal activity according to sex in response to hunger and satiety even though there is no differences by sex in subjective ratings of hunger and satiety in response to controlled administration of an energy load. Other scientists found that the cortical activity of women in response to foodrelated stimuli was higher compared to men [17]. Among GI hormones, ghrelin concentrations were significantly higher in females compared to males both in a fasting state and in response to oral glucose and lipid loads [18.19]. Whey protein supplement increased total energy intake in women compared to men [20]. Gastric emptying was slow and plasma glucagon, CCK and GLP-1 increased less in women than men [20]. So, it is questionable whether PFB would show the same effect in both sex.

\section{CONFLICTS OF INTEREST}

No potential conflict of interest relevant to this article was reported.

\section{REFERENCES}

1. World Health Organization: Overweight and obesity. Available from: https://www.who.int/news-room/fact-sheets/detail/obesity-and-overweight (updated $2018 \mathrm{Feb} 16$ ).

2. American Diabetes Association. 5. Facilitating behavior change and well-being to improve health outcomes: standards of medical care in diabetes-2020. Diabetes Care 2020;43(Suppl 1):S4865.

3. Ahn $\mathrm{CH}, \mathrm{Bae} J \mathrm{H}$, Cho YM. Premeal consumption of a proteinenriched, dietary fiber-fortified bar decreases total energy intake in healthy individuals. Diabetes Metab J 2019;43:879-92.

4. Rolls BJ. The relationship between dietary energy density and energy intake. Physiol Behav 2009;97:609-15.

5. Blundell JE, Burley VJ, Cotton JR, Lawton CL. Dietary fat and the control of energy intake: evaluating the effects of fat on meal size and postmeal satiety. Am J Clin Nutr 1993;57(5 Suppl): 772S-7S.

6. Blundell JE, MacDiarmid JI. Fat as a risk factor for overconsumption: satiation, satiety, and patterns of eating. J Am Diet Assoc 1997;97(7 Suppl):S63-9.

7. Paddon-Jones D, Westman E, Mattes RD, Wolfe RR, Astrup A,
Westerterp-Plantenga M. Protein, weight management, and satiety. Am J Clin Nutr 2008;87:1558S-61S.

8. Johnstone AM, Stubbs RJ, Harbron CG. Effect of overfeeding macronutrients on day-to-day food intake in man. Eur J Clin Nutr 1996;50:418-30.

9. Tome D, Schwarz J, Darcel N, Fromentin G. Protein, amino acids, vagus nerve signaling, and the brain. Am J Clin Nutr 2009; 90:838S-43S.

10. Woods SC. Metabolic signals and food intake. Forty years of progress. Appetite 2013;71:440-4.

11. Moran TH, Dailey MJ. Intestinal feedback signaling and satiety. Physiol Behav 2011;105:77-81.

12. Tremblay A, Bellisle F. Nutrients, satiety, and control of energy intake. Appl Physiol Nutr Metab 2015;40:971-9.

13. Juvonen KR, Purhonen AK, Salmenkallio-Marttila M, Lahteenmaki L, Laaksonen DE, Herzig KH, Uusitupa MI, Poutanen KS, Karhunen LJ. Viscosity of oat bran-enriched beverages influences gastrointestinal hormonal responses in healthy humans. J Nutr 2009;139:461-6.

14. Vuksan V, Rogovik AL, Jovanovski E, Jenkins AL. Fiber facts: benefits and recommendations for individuals with type 2 diabetes. Curr Diab Rep 2009;9:405-11.

15. Burton-Freeman BM. Glycomacropeptide (GMP) is not critical to whey-induced satiety, but may have a unique role in energy intake regulation through cholecystokinin (CCK). Physiol Behav 2008;93:379-87.

16. Del Parigi A, Chen K, Gautier JF, Salbe AD, Pratley RE, Ravussin E, Reiman EM, Tataranni PA. Sex differences in the human brain's response to hunger and satiation. Am J Clin Nutr 2002; 75:1017-22.

17. Smeets PA, de Graaf C, Stafleu A, van Osch MJ, Nievelstein RA, van der Grond J. Effect of satiety on brain activation during chocolate tasting in men and women. Am J Clin Nutr 2006; 83:1297-305.

18. Greenman Y, Golani N, Gilad S, Yaron M, Limor R, Stern N. Ghrelin secretion is modulated in a nutrient- and gender-specific manner. Clin Endocrinol (Oxf) 2004;60:382-8.

19. Geary N. Estradiol, CCK and satiation. Peptides 2001;22:125163.

20. Giezenaar C, Luscombe-Marsh ND, Hutchison AT, Lange K, Hausken T, Jones KL, Horowitz M, Chapman I, Soenen S. Effect of gender on the acute effects of whey protein ingestion on energy intake, appetite, gastric emptying and gut hormone responses in healthy young adults. Nutr Diabetes 2018;8:40. 